\title{
NATIONAL VECTORS OF THE IMPLEMENTATION OF AGRICULTURAL LAND PLOTS MARKET IN UKRAINE
}

Dorosh O.S., Doctor of Economics, Professor, National University of Life and Environmental Sciences of Ukraine, Kyiv, dorosholgas@ukr.net

Fomenko V.V., Ph.D., associate professor, Odesa State Agrarian University, Odesa,ph.d.fomenko@gmail.com

Tretiachenko D.V., Postgraduate Student, National University of Life and Environmental Sciences of Ukraine, Kyiv, tretyachenkodmytro@gmail.com

It is revealed that the presence of institutional constraints precludes the full use of the potential of agricultural lands as a complete component of commodity-money relations. In view of this, the rather complicated, multifaceted problem of new institutes installation in the development of agricultural land plots market is scientifically substantiated. In this correspondence, the national vectors of influence on the introduction of the market of agricultural land plots in Ukraine have been formed and singled out, namely: trust in the authorities, stability of financial and credit institutions and the independence of the judicial branch of power. It is proved that the cancellation the moratorium on the sale of these land plots will be expedience only after the formation of institutes, which will require a certain time interval of several years.

Key words: market of agricultural land plots, institutes, economic and legal support, institutional support, moratorium.

Formulation of the problem. The system of laws, regulations and requirements that determine the behavior of all parties when entering into transactions in the process of market exchange is nothing more than the institutional basis of the market of land plots. Institutions are in need of change, as restrictions on the powers of the right holders have a negative impact on both the possibility of attracting long-term investments in the capitalization of agricultural land and on the domestic competition on the market of land plots at the local level. Thus, the change of institutions will promote the protection of land ownership rights in the direction of economic growth 
of local markets and their integration into a national and, to some extent, international exchange. At the same time, the market of land plots cannot be considered as a selfsufficient mechanism of growth of national wealth of the state. The change in its components must take place through the transformation of the institutional framework in which land relations are developed and regulated.

In view of the fact that the institutes are not currently formed, the cancellation of moratorium on the sale of agricultural land plots in the next few years is not appropriate, because these few years will be necessary for their formation. The solution of the economic-legal and institutional support for the formation of the market of agricultural land plots in the context of the implementation of the European vector of development of Ukraine will also be required. In this correspondence, there is a need for the allocation of national vectors for the implementation of this process.

Analysis of recent research and publications. An overview of the scholarly works that raise this issue is evidence that the introduction of the land market in Ukraine is currently the most controversial issue, due to the lack of a unified position among many scholars, specialists, and public figures in relation to its solution. The works of A. Danylenko, I. Dorosh, V. Zayats, S. Ibatullin, P. Kulinich, Yu. Lupenko, A. Martyn, L. Novakovskyi, B. Paskhaver, A. Tretiak, M. Fedorov and others deserves special attention.

The complexity of the situation regarding the introduction of the market of agricultural land plots is due to existing institutional constraints, which hinder the full use of the potential of agricultural land as a complete component of commoditymoney relations.

Normative monetary valuation of land in Ukraine does not exceed $\$ 300$ billion. The market value of these lands, according to estimations of S. Ibatullin, is about $\$ 1.5$ trillion dollars. In this respect, the most underestimated is agricultural land: about $\$ 40$ billion according to normative monetary valuation, as opposed to $\$ 225$ billion - the market estimation. For example, the assets of the entire Ukrainian banking system amounted to $\$ 48$ billion (but in the global dimension it is scant money). The proof of this is that one large European bank has assets of over $\$ 2$ 
trillion, and Chinese - more than $\$ 4$ trillion. In view of this, Ukrainian assets need to be capitalized, otherwise they will become uncompetitive [6].

In this case, a complex, multidimensional problem of installing of new institutions in the development of agricultural land plots market needs a systematic scientific comprehension.

The purpose of the paper is to study the problematic aspects of economic, legal and institutional support for the development of the market of agricultural land plots in Ukraine and to form national vectors of influence on its implementation.

Presentation of the research. The complex and contradictory processes of the transformation of land ownership relations, the non-formation of institutes, the negative attitude of Ukrainian society to the free circulation of agricultural land plots are those levers that restrain the existing potential of 42.72 million hectares of agricultural land, of which arable land is 32.54 million hectares, from becoming the basis for Ukraine's economic, food and energy security. Undoubtedly, there is no alternative to implementation of the agricultural land plots market because its phased introduction is synchronized with the Strategy for the development of the agrarian sector of the economy for the period till 2020 as one of the priority directions of the reform of the agrarian sector [9]. In addition, the black market of agricultural land plots in Ukraine works uncontrollable by the state (accordingly, the black loan market also operates).

However, the initiative to implement the agricultural land plots market has not found support in society, as evidenced by the results of the survey of the small and medium agrarian businesses and farmers representatives at the All-Ukrainian Land Forum in Kyiv on April 10, 2019, organized by the All-Ukrainian Agrarian Council. $66.9 \%$ of respondents found the implementation of the agricultural land plots market negative for them. They indicated that they are not able to compete with holding companies, officials and oligarchs, in case of implementation of the agricultural land plots market (490 agribusiness enterprises engaged in economic activity on the lands with a total area of 4.5 million hectares took part in the vote) [5].

In the current situation, it is necessary to form and highlight the national vectors of the most important influence on the implementation of the market of agricultural 
land plots. First, trust in the government, which seeks for real reform (the presence of mechanisms, tools, norms, standards and rules, participation in all-Ukrainian thematic forums, etc.), secondly, justice (the independence of the judicial branch) and third is the stability of financial and credit institutions.

In this regard, thematic forums and roundtables of different stakeholders, such as: agroholdings' owners, middle agricultural enterprises and private farmers, owners of land shares, scientists, agricultural associations, UTCs, experts, public organizations, bankers, lawyers should precede the implementation of the agricultural land plots market, that will provide the reform with higher value. The results of such discussions should be published for an all-Ukrainian discussion, to find support in the majority of Ukrainian people, taking into account them when drafting the Law "On the market of agricultural land plots", which implementation would be acceptable for all interested stakeholders.

In addition, this law must contain two components: a) political; b) technical. This is due to the fact that the introduction of a market of agricultural land plots requires mechanisms, tools, norms, rules and standards, on the basis of which the corresponding infrastructure is formed (exchanges, auctions, etc.). The political component is implemented on the basis of selected principles, and technical - on the basis of norms, rules and standards, which are developed taking into account these principles (their observance is a prerequisite). We will prove their compulsory nature on a rather simple example: if the land plot holder strives to sell it at its own discretion, this will lead to both conflict situations and violate the integrity of the arrays of agricultural land, which is inappropriate from an economic point of view.

The complexity of the implementation of the market of agricultural land is emphasized by the inadequate filling of the State Land Cadastre with the information about all its objects. In accordance with the Law of Ukraine "On State Land Cadastre", such objects include: 1) land within the state border of Ukraine; 2) land within the territory of administrative-territorial units; 3) restrictions on the use of land; 4) a land plot. At the legislative level, it is settled that information about the objects of the State Land Cadastre during their introduction into the State Land Cadastre must correspond to the existing characteristics of the objects determined 
with accuracy defined in accordance with the state standards, norms and rules, technical regulations [3].

It is important to note that the non-formation of the boundaries of settlements significantly affects the filling of the information of this registration system. According to the State Service for Geodesy, Cartography and Cadastre, as of December 10, 2018, there are 28670 settlements (excluding the Crimea), of which only 21529 (75.1\%) have formed boundaries. However, the State Land Cadastre only contains information on the boundaries of 1850 settlements, which is $16 \%$ of the total $[10$, p. 6]. And with the creation of united territorial communities, this process is going to be much more complicated.

There is not the best situation with information entered in the State Land Cadastre related to land shares and restrictions on land use. According to the data of the State Service for Geodesy, Cartography and Cadastre, only $75 \%$ of the land shares and about $10 \%$ of restrictions on land use are registered. For example: when buying a land plot without the specified restrictions in the use of land, we get into a situation where within this area there is a gas pipeline (such a plot can be sowed by any crops, but gardening is forbidden, etc.), but if the restrictions are not registered, it is hard to control such things.

Therefore, the registration system is a guarantor of property rights, which contributes to the improvement of the culture of contractual relations, which allows to increase the liquidity and value of property rights. And official confirmation of the identification of property objects allows us to expand the range of economic assets. Uncertainty regarding the identification of forms and ownership rights to agricultural land is negatively reflected in court decisions.

In addition, the judicial system in Ukraine needs to increase the quality and independence of the judiciary. The rule of law, effective and independent justice and public confidence in the courts are key to promoting the implementation of the market of agricultural land plots.

In Ukraine, there is a risk of concentrating large areas of agricultural lands in the hands of agroholdings. This is explained by the fact that the areas of the holding's land use and its number in Ukraine grows year by year and this trend is increasing. 
From 2012 to 2017 their number has increased from 80 to 93 . Each of them uses more than 10 thousand hectares of agricultural land. In addition, the total land bank of agroholdings has increased over five years from 5.6 million hectares to 5.95 million hectares (in 2017), and an increase in agricultural land in the use of this category of enterprises is $6.3 \%$ [1].

In scientific circles there is the opinion that the activity of agroholdings relate in a certain extent to the negative trends in the development of rural areas, namely: "... 1) concentration of land and, consequently, monopolization of a market of land lease and agricultural products market; 2) absorption by the agrarian business of traditional rural areas, its infrastructure and forms of agricultural production, farms; 3) there is a reduction in the labor market due to the use of advanced technologies, highperformance equipment; 4) since the head office of agricultural holdings is registered in large cities, local budgets receive less taxes and other payments that could be used for the development of territorial communities; 5) for the most part monoculture production is carried out, which is not accompanied by the introduction of organic fertilizers (livestock is practically not engaged); 6) the state of agricultural lands deteriorates as a result of high intensity exhausting agriculture "[2, p. 17].

Agroholdings in their activities must adhere to the law, social justice, not forgetting the environmental component. Nevertheless, farms have a greater socioeconomic effect in rural areas, they are more environmentally conscious [8].

Consequently, monopolization leads to negative consequences, which to a certain extent will contribute to the loss of land ownership by large part of citizens. This is due to the fact that there are global trends that will be applied to Ukraine as well. During economic growth, the number of deals with real estate is about $10-12 \%$ of the total number of objects, and during the economic recession is reduced to $2-3 \%$. Given that in Ukraine there are about 6 million agricultural land plots, then about 200 thousand plots (about 3\% of the total number) can be offered for sale at the same time. The starting selling price, taking into account all risks, can reach $\$ 1,000$ per hectare, and as a result, their value will reach $\$ 200$ million. Such money is available only for domestic agricultural holdings and foreign funds, which are not indifferent to our lands. By contrast, there is no such amount of money in farmers' and small-scale 
producers' hands. Therefore, the speculators will buy up agricultural land for resale (200 million dollars are to invest in the start-up, which on the output can multiply your investments by 3-5 times). At the same time, we would like to note that the cost of Ukrainian lands according to the fertility potential should exceed the amount of 10 thousand US dollars per 1 hectare. Only by attracting foreign investments it is possible to reach such prices in the market, but for now it is not permissible, because under these circumstances the beneficiaries will be foreign funds and several agricultural holdings in Ukraine [7].

The above can be considered as an indisputable proof that for rural inhabitants who work on land, in case of need for its acquisition - at the legislative level absolute right to purchase land on the basis of lease if the state can create special funds and land banks for this, or a possibility to taking a loan in a bank, without mortgage the land plot (availability of state insurance funds that insure loans) should be guaranteed [5].

We consider it expedient to limit the term for the alienation of a land plot of agricultural purpose granted or purchased for commercial agricultural production or farming for at least two years from the date of its acquisition, except in the following cases: a) alienation for the purpose of consolidation of agricultural land masses in accordance with the law; b) alienation of a land plot by a court decision; c) alienation of a land plot by a person to whom the land may not belong to the right of ownership in accordance with Article 145 of the Land Code [4].

In case of transfer of ownership of a land plot to a person who cannot be in its ownership, under the rules of the current land law, it is subject to alienation by its owner during the year from the moment of transfer of such right. If the land plot of such person during the established term is not alienated - it is a subject to compulsory alienation by a court decision (on the basis of a statement of the authority exercising control over the use and protection of land).

It is important that the pre-emptive right to purchase agricultural land allocated for commercial agricultural production or farming, belonged to: 1) members of the family of the owner of the land; 2) owners and users of adjacent agricultural land 
which have been using them for the last three years; 3) farms that are located and registered in the respective territorial communities.

The land of agricultural purpose of state, communal and private property will definitely be owned exclusively by citizens of Ukraine for the conducting of a personal peasant farm (up to 20 hectares) or a middle farming (up to 200 hectares) without the status of a legal entity and who have been producers of agricultural products for the last three years, and their revenues from farming during this period amounted at least $75 \%$ of their revenues.

It is important to provide the prohibition or imposition of strict restrictions on the change of the purpose of land plots (not earlier than 5 years after the date of acquisition by the owner of the property right) in order to prevent the uncontrolled transfer of agricultural land to another category of purpose, unless, by virtue of natural processes (afforestation, waterlogging, etc.) the land plot has become unproductive, so it is not expedient to use it for agricultural production. The condition of buying a land plot of agricultural purpose is the presence of documents, confirming the legality of acquiring funds, which is planned to use for purchasing the agricultural land plot.

It should be noted that the sale price of agricultural land owned privately cannot be lower than their normative monetary valuation. And the sale price of a land plot of agricultural purpose of state and communal property may not be lower than its expert monetary valuation carried out at the time of sale in accordance with the law, except for land plots sold on land trades. Sale of land plots of state or communal property or rights to them (lease, superficies, emphyteusis) should take place exclusively on electronic land auctions. Some exceptions established at the legislative level in the article 134 of the Land Code of Ukraine [4].

An important vector for the implementation of an effective market of agricultural land plots in Ukraine should be the work of a specialized financial and credit institution - the Agrarian Bank of Ukraine and its subdivisions in regions that will facilitate the movement of funds and pledges of property rights in order to obtain cheap credits (up to $3 \%$ per annum) by agricultural producers. 
Conclusions. The unsystematic nature of the socio-political transformations within the national economic system over the past few years in Ukraine has had a negative impact on the economic, legal and institutional basis for the implementation of the market of agricultural land plots. In this regard, only thanks to the cooperation of scientists, professional domestic and international experts, economists and the public in the coming years, we can achieve positive results.

Undoubtedly, there is no alternative to the implementation of the market of agricultural land plots. Therefore, in our opinion, it is necessary to implement the national vectors of influence on the introduction of the market of agricultural land plots, namely: 1) trust in the government, which seeks for real reform (the presence of mechanisms, tools, norms, standards and rules, participation in all-Ukrainian thematic forums); 2) justice (independence of the judicial branch of power); 3) the stability of financial and credit institutions.

\section{REFERENCES}

1. Ekonomichna pravda (2018). Agroholdings concentrated one third of agricultural enterprises lands. Available at: https://www.epravda.com.ua/news/2018/06/15/637812/

2. Dorosh O.S., Kupriianchyk I.P. (2016). Rol sotsialno-ekonomichnoii i instytutsiinoii skladovykh u formuvanni i funktsionuvanni ahrokholdynhiv v Ukraini [The role of socio-economic and institutional components in the formation and functioning of agroholdings in Ukraine. Land management], cadastre and land monitoring, $3,12-19$.

3. Law of Ukraine "On State Land Cadastre" (2011) Available at: http://zakon.rada.gov.ua/laws/show/3613-17\#n369

4. The Land Code of Ukraine (2001). Available at: https://zakon.rada.gov.ua/laws/show/2768-14

5. Land news (2019). Land Bulletin of Ukraine. Available at: http://zemvisnuk.com.ua/page/news1

6. Ibatullin Sh. (2019). Normative monetary valuation of Ukrainian lands. Available at: https://www.facebook.com/shamil.ibatullin.5/posts/641325006312892 
7. Lutskiy A. (2018). Esli zemly v Ukraine skupyat 4-5 agroholdingov, eto budet novoe krepostnoe pravo [If 4-5 agroholdings buy land in Ukraine, it will be a new serfdom]. Land Bulletin of Ukraine. Available at: http://zemvisnuk.com.ua/page/sv-zh-publ-kats-zm-6

8. Propozytsia (2017). Rozmir zemelnoho banku ahrokholdynhiv ta ikhnia kilkist v Ukraini schoroku zrostaiut [The size of the land bank of agroholdings and their number in Ukraine are increasing each year]. Available at: https://propozitsiya.com/ua/rozmir-zemelnogo-banku-agroholdyngiv-ta-yihnyakilkist-v-ukrayini-shchoroku-zrostayut

9. Ministry of Agrarian Policy and Food of Ukraine (2013). Stratehiia rozvytku ahrarnoho sektoru ekonomiky na period do 2020 roku [Strategy for the development of the agrarian sector of the economy for the period up to 2020]. Available at: http://minagro.gov.ua/node/7644

10. Modern technologies and land: what to expect? (2019). Zemlevporiadnyi visnyk, $3,2-8$.

\section{НАЦІОНАЛЬНІ ВЕКТОРИ ЗАПРОВАДЖЕННЯ РИНКУ ЗЕМЕЛЬНИХ} ДІЛЯНОК СІЛЬСЬКОГОСПОДАРСЬКОГО ПРИЗНАЧЕННЯ В УКРАЇНІ

Дорош О.С., д.е.н., професор, Національний університет біоресурсів $i$ природокористування України, м. Київ, dorosholgas@ukr.net

Фоменко В.А, к.е.н., доцент, Одеський державний аграрний університет, M.Odeca, ph.d.fomenko@gmail.com

Третяченко Д.В., аспірант, Наџіональний університет біоресурсів $i$ природокористування України, м. Київ, tretyachenkodmytro@gmail.com

3'ясовано, щэо наявність інституиійних обмежень перешкоджає у повній мірі використовувати потенціал земель сільськогосподарського призначення як повночінну складову товарно-грошових відносин. 3 огляду на ие, науково обтрунтовано доволі складну, багатоаспектну проблему умонтування в розбудову ринку земельних ділянок сільськогосподарського призначення нових інститутів. У иій відповідності сформовано та виокремлено національні вектори впливу стосовно запровадження ринку земельних ділянок 
сільськогосподарського призначення в Україні, а саме: довіра до влади, стабільність фінансово-кредитних інститутів і незалежність судової гілки влади. Встановлено й доведено дочільність скасування мораторію на продаж зазначених ділянок після формування інститутів для чого знадобиться певний відтинок часу розрахований на кілька років.

Ключові слова: ринок земельних ділянок сільськогосподарського призначення, інститути, економіко-правове забезпечення, інституційне забезпечення, мораторій.

\section{СПИСОК ВИКОРИСТАНИХ ДЖЕРЕЛ}

1. Агрохолдинги сконцентрували третину земель сільгосппідприємств // Економічна правда - 2018. - [Електронний ресурс]. - Режим доступу: https://www.epravda.com.ua/news/2018/06/15/637812/

2. Дорош О.С., Купріянчик І.П. Роль соціально-екномічної й інституційної складових у формуванні й функціонуванні агрохолдингів в Україні // Землеустрій, кадастр і моніторинг земель. - № 3. - 2016. - с. 12 - 19.

3. Закон України «Про Державний земельний кадастр» // Відомості Верховної Ради України (ВВР). - 2011. - [Електронний ресурс]. - Режим доступу: http://zakon.rada.gov.ua/laws/show/3613-17\#n369

4. Земельний кодекс України // Відомості Верховної Ради України (ВВР). - 2001. - [Електронний ресурс]. - Режим доступу: https://zakon.rada.gov.ua/laws/show/2768-14

5. Земельні новини // Земельний вісник України - 2019. - [Електронний pecypc]. - Режим доступу: http://zemvisnuk.com.ua/page/news1

6. Ібатуллін Ш. Нормативна грошова оцінка земель України - 2019. [Електронний ресурс]. https://www.facebook.com/shamil.ibatullin.5/posts/641325006312892

7. Луцкий А. Если землю в Украине скупят четыре-пять агрохолдингов, это будет новое крепостное право // Земельний вісник України - 2018. [Електронний ресурс]. - Режим доступу: http://zemvisnuk.com.ua/page/sv-zhpubl-kats-zm-6 
8. Розмір земельного банку агрохолдингів та їхня кількість в Україні щороку зростають // Пропозиція - 2017. - [Електронний ресурс]. - Режим доступу: https://propozitsiya.com/ua/rozmir-zemelnogo-banku-agroholdyngiv-tayihnya-kilkist-v-ukrayini-shchoroku-zrostayut

9. Стратегія розвитку аграрного сектору економіки на період до 2020 року // Міністерство аграрної політики та продовольства України - 2013. [Електронний ресурс]. - Режим доступу: http://minagro.gov.ua/node/7644

10. Сучасні технології та земельна галузь: чого чекати? // Землевпорядний вісник, № 3, 2019, с. 2 - 8 .

O. Dorosh, V. Fomenko, D. Tretiachenko

NATIONAL VECTORS OF THE IMPLEMENTATION OF AGRICULTURAL LAND PLOTS MARKET IN UKRAINE

It is revealed that the presence of institutional constraints precludes the full use of the potential of agricultural lands as a complete component of commodity-money relations. In view of this, the rather complicated, multifaceted problem of new institutes installation in the development of agricultural land plots market is scientifically substantiated. In this correspondence, the national vectors of influence on the introduction of the market of agricultural land plots in Ukraine have been formed and singled out, namely: trust in the authorities, stability of financial and credit institutions and the independence of the judicial branch of power. It is proved that the cancellation the moratorium on the sale of these land plots will be expedience only after the formation of institutes, which will require a certain time interval of several years.

Key words: market of agricultural land plots, institutes, economic and legal support, institutional support, moratorium.

Дорош О.С., Фоменко В.А., Третяченко Д.В.

НАЦИОНАЛЬНЫЕ ВЕКТОРЫ ВВЕДЕНИЕ РЫНКА ЗЕМЕЛЬНЫХ

УЧАСТКОВ СЕЛЬСЬКОХОЗЯЙСТВЕННОГО НАЗНАЧЕНИЯ В 
Установлено, что наличие институц̧иональных ограничений препятствует в полной мере использовать потенциал земель сельскохозяйственного назначения как полноценную составляющую товарноденежных отношений. Учитывая это, научно обоснованно довольно сложную, многоаспектную проблему встраивания в развитие рынка земельных участков сельскохозяйственного назначения новых институтов. В этом контексте сформировань и вылделены национальные векторы влияния относительно введения рынка земельных участков сельскохозяйственного назначения $в$ Украине, а именно: доверие к власти, стабильность финансово-кредитных институтов и независимость судебной ветви власти. Установлено и доказано целесообразность отмены моратория на продажу указанных участков после формирования институтов для чего понадобится определенный отрезок времени рассчитан на несколько лет.

Ключевые слова: рынок земельных участков сельскохозяйственного назначения, институты, экономико-правовое обеспечение, институциональное обеспечение, мораторий. 